\title{
Role of ankle taping and bracing in the athlete
}

\author{
Michael J Callaghan
}

\begin{abstract}
Adhesive tape is often used to help athletes recover from ligament sprains of the ankle or to prevent further injury. The choice of taping technique or material is often decided by personal preference, superstition, or anecdote. More recently, the use of ankle braces has become more prevalent, but reasons for their use are similarly variable. As ankle sprains are a major cause of an athlete's disability and time off sport, the choice of the method of support should be more scientifically reasoned. This paper attempts to review the literature concerning the effects of various methods of ankle support on swelling, stability, range of movement, proprioception, muscle function, gait, and performance tests. There is still some contradiction in the literature about the effects of taping and braces in both the acute and chronic phases of ligament sprains of the ankle.

(Br F Sports Med 1997;31:102-108)
\end{abstract}

Athletes from many sports consider taping and bracing to be important in the acute and chronic phases of an ankle injury. Indeed, many sportspeople consider ankle support to be essential to their performance, with the corollary that their performance may suffer without such support. Most published reports on the efficacy of taping and bracing focus on their use on the ankle joint. This is probably, in part, because ankle sprains are the most common sports injury, ${ }^{1}$ with the incidence varying from $10 \%$ to $30 \%$ of all musculoskeletal injuries. ${ }^{2}$ In a soccer season, players have a $25 \%$ chance of having an ankle sprain if they have had a previous sprain, and $11 \%$ if they were previously problem free. ${ }^{3}$ The focus on the ankle may also be because it is easy to measure the effects of tape and braces on range of motion, gait, functional and muscle performance. ${ }^{4}$ Ankle support is used to control swelling and range of motion in the acute stage, and to provide support or stability to the ligaments and joint in the chronic stage when the athlete returns to sport. However, the use of different taping techniques and braces is dictated more by considerations of cost, comfort, ease of application, personal preference, age, and the type of sport. ${ }^{5}$ Physiotherapists and other personnel who apply tape and braces to athletes need to be aware of the evidence for and against the use of both these methods. In this way, rehabilitation procedures after an ankle injury, or prophylactic advice, can be applied more scientifically.
This paper sets out to review the literature on taping and presents the scientific evidence available to suggest why taping helps support ankles and prevents ankle sprains. It also considers the role of ankle braces, which increasingly are being investigated and used instead of taping.

\section{Methods}

Computerised searches were performed using Medline, Excerpta Medica, and CINAHL for studies published between 1966 and 1996. Only English language publications were considered. Keywords used alone or in combination were: ankle sprain, taping, orthosis, brace, inversion injury, rehabilitation, athletic performance, proprioception, peroneal muscle. Other references were identified from some existing reviews and from other papers cited in the publications searched. There were also some other papers found in the author's personal collection.

\section{Anatomy and pathomechanics}

The ankle joint receives its strongest support from the medial and lateral collateral ligaments. The lateral collateral ligament is composed of three bands: the anterior talofibular ligament, which attaches from the neck of the talus to the tip of the fibula; the posterior talofibular ligament, which runs from the body of the talus to the tip of the fibula; and the calcaneofibular ligament, which runs from the calcaneus to the tip of the fibula.

Acute lateral ankle sprain is generally accepted to be the most common sports related ligamentous injury, ${ }^{6}$ accounting for $85 \%$ of all sprains. ${ }^{2}$ This results in damage to the lateral ligament complex with the anterior talofibular ligament being most often damaged; this is probably because it has the weakest tensile strength of the lateral complex. ${ }^{6}$ The most common mechanism for an ankle sprain is excessive inversion usually accompanied by slight plantarflexion and some internal rotation. Some sports like basketball and volleyball have high ground reaction forces when players land from a high jump, which accentuates the sprain and the rate of injury. This accounts for these sports having $79 \%$ and $87 \%$ of inversion sprains respectively and 2.5 times more ankle injuries than walking or hiking. ${ }^{7}$ The incidence of ankle sprains in football (soccer) is $31 \%$, in American football $17 \%$, and in ballet $17 \%$.

\section{Taping technique}

The taping technique used by athletes and physiotherapists is often governed by personal preference, the experience of the person applying the tape, and a general "feel" as to the 
correct technique. This may be due, in part, to the lack of comparative studies between the different taping techniques.

Rarick et al investigated the resistance provided by different zinc oxide techniques on plantarflexion and inversion of the ankle. ${ }^{8}$ After 10 minutes of vigorous exercise they found the greatest tensiometer readings of mean resistance were offered by a basketweave with stirrup and heel lock technique, closely followed by basketweave and heel lock. Frankney et al compared four zinc oxide taping techniques "Hinton-Boswell"; basketweave; "basic"; "Gill") with an unspecified brace and an untaped group. ${ }^{9}$ They analysed their resistance to mechanical inversion and concluded that the Hinton-Boswell method (in which the ankle is taped in a relaxed plantarflexed position) provided greatest resistance to inversion. They speculated that this may be due to a combination of factors, such as mechanical limitation, kinaesthetics, and the subconscious effect on the athlete. Whereas these two studies could be classed as "in vivo" work, Pope et al used a model construction of an ankle to perform, in effect, an "in vitro" study of different taping techniques. ${ }^{10}$ They measured the ability of the $2.5 \mathrm{~cm}$ zinc oxide tape to resist applied torque, angular deflection, and "stiffness"-the last being calculated by dividing torque by angular deflection. They found angular deflection greater than $8^{\circ}$ was prevented by a figure of eight plus stirrup technique; torque load to 420 $\mathrm{Nm}$ was withstood by a figure of eight with three wraps technique; the stiffest configuration was a figure of eight plus stirrup technique. Although the authors conceded that there were many dangers in extrapolating their results to the human ankle, it indicated the amount of force needed to make tape fail.

\section{Bracing}

Ankle braces have advantages over tape in being self applied without needing the expertise of qualified personnel, convenient to apply and remove, ${ }^{11}$ reusable, readjustable, and washable. Also, skin problems are less common, especially among those athletes who have an allergic reaction to Elastoplast or zinc oxide. These ready made braces are of various materials, thus providing varying amounts of support and stability and are broadly differentiated as "non-rigid" or "semirigid". The nonrigid braces are often made of canvas or a neoprene-type material, which can easily be slipped on and off, some with additional lacing. The semirigid braces mostly consist of bimalleolar struts made of thermoplastic materials attached by Velcro straps. A number of studies have established the role of braces in restricting the amount of movement, especially inversion at the ankle, on healthy uninjured athletes. These studies have measured the effects of braces such as the non-rigid "Nessa ankle support" and "Leuko functional ankle brace" on inversion in $42^{\circ}$ plantarflexion after 40 minutes' exercise ${ }^{12}$; the non-rigid "subtalar stabiliser" on calcaneal inversion after $15 \mathrm{~min}$ utes' vigorous exercise ${ }^{13}$; and on inversion/ eversion total motion using the semirigid
Aircast airstirrup ${ }^{14-16}$; the semirigid Donjoy $\mathrm{ALP}^{16-18}$; the non-rigid canvas Swede-Ouniversal brace. ${ }^{16}$ All these studies found significant reduction of ankle movement after applying a brace to an $\alpha$ level of 0.05 or greater. However, it is important to note that the Swede-O-universal brace could be converted to a semirigid type by sliding plastic struts in the side pockets on the brace. The authors do not stipulate which version they used.

Taping and bracing for acute ankle sprain After an acute ligament sprain compressive strapping is often recommended and applied to control oedema. ${ }^{19}$ Few studies have been performed or published to evaluate the efficacy of taping to achieve limb or joint compression. Hall (unpublished data) used volumetry to study the control of ankle joint swelling with treatment after an acute ankle lateral ligament sprain. He found that ice and compression taping (which included a horseshoe shaped felt pad around the lateral malleolus) achieved better control of swelling than ice and ultrasound over a period of 10 days.

Capasso et al compared the effect of adhesive and non-adhesive tape on swelling. ${ }^{20}$ They concluded that non-adhesive tape should be renewed after three days owing to insufficient compression, but that adhesive tape could last five days before renewal. This study measured the compressive forces of each type of tape by using a sphygmomanometer cuff included in the taping. However, this has been criticised in earlier work by Viljakka as being an inexact method of measurement. ${ }^{21}$ The latter study used a plastic fluid chamber as measurement and compared Elastoplast and Tensoplast with various padded and elastic bandages. ${ }^{21}$ In ankle taping the most significant decrease in pressure was found after 15 minutes' walking and thereafter stayed constant, indicating that either the padded adhesive or the elastic bandage was the most suitable for bandaging the ankle.

The role of an ankle brace in controlling oedema after acute ankle sprain was investigated by Stover using the Aircast airstirrup. ${ }^{22}$ Wishing to highlight the brace's "milking effect on oedematous tissues", he noted that the brace with its inner airbag exerted $25 \mathrm{mmHg}$ pressure, which increased to $50 \mathrm{mmHg}$ when weight bearing and $75 \mathrm{mmHg}$ in full dorsiflexion.

Epidemiological studies have tried to establish the ability of tape and braces to prevent an acute ankle injury over a playing season or year. The most commonly cited study on injury prevention is that of Garrick and Requa, ${ }^{1}$ which studied the effect of taping on 2563 basketball players with previous ankle sprains over two successive seasons. They observed that a zinc oxide stirrup with horseshoe and figure of eight technique in conjunction with a high support basketball shoe gave an injury incidence of 6.5/ 1000 games. The untaped players with the same shoe had an incidence of 30.4/1000 games. Taping with a low support shoe gave an injury incidence of 17.6/1000 games. From these data they concluded that taping had a 
protective influence for preventing ankle sprains, though the role of high or low top shoes in helping stability is unclear. ${ }^{23}$

Ankle braces may also reduce the incidence and severity of acute ankle sprains in competition, ${ }^{24}$ as has been examined, for example, in basketball players. ${ }^{25}$ The use of an Aircast stirrup in a control group and in 1601 players was compared over two years. It was calculated that the brace significantly reduced the frequency of ankle injury; the players without the orthosis had three times the risk of ankle injury. Tropp et al studied the effect of an ankle brace compared with a proprioception programme in $\mathbf{4 5 0}$ soccer players and a control group over a six month period. ${ }^{3}$ In previously uninjured players the incidence of ankle sprain was $3 \%$ for bracing, $5 \%$ for proprioception training, $11 \%$ controls. However, if a player had previous ankle injuries, the incidences were $2 \%$ for bracing, $5 \%$ proprioception, and $25 \%$ controls. This indicated that both proprioception training and bracing had significantly lowered the incidence of ankle sprains, especially if the ankle had been previously sprained. The preventive effect of braces on sprains in soccer players was confirmed by a later prospective, randomised study using a large sample of 600 players. ${ }^{26}$ This finding (also noted in laboratory studies ${ }^{27}$ ) was thought to be due to improving the defective stabilisation of the peroneii muscle group. Although the studies reviewed provide important information about the efficacy of tape or a brace, the study design, external validity, confounding variables, and sample size have been criticised. ${ }^{28}$ These factors should also be considered before selecting the appropriate technique or device.

Other studies have directly compared traditional taping methods and ankle braces in the prevention of acute ankle sprain. Rovere et $a l^{29}$ conducted a retrospective study over a seven year period on 297 American footballers and concluded that, compared with taping, an apparently non-rigid (but not specified) lace up ankle brace halved the risk of ankle sprain injury. They speculated that this may be because the athletes can readjust the tension of the brace regularly during exercise. Ankle bracing also provided greater socioeconomic benefits as shown when comparing compressive bandaging with a semirigid Aircast airstirrup. $^{30}$ Two matched groups were treated for three weeks by either method after an acute ankle sprain. The group treated with the Aircast airstirrup was more mobile in the initial phase of rehabilitation and had a shorter sick leave. They also calculated that the cost of the semirigid brace was regained after a half day earlier return to work.

\section{Taping and bracing for chronic ankle sprain}

The paucity of work published on the effects of tape and braces on acute ankle injury is in contrast with the volume of research into the effects of taping on the chronically sprained ankle. Tape and braces are applied at this stage when the athlete has recovered from the acute phase and is returning to sport. Their use in the chronic phase addresses the problem of ankle instability, which may be mechanical or functional. ${ }^{31}$

\section{MECHANICAL INSTABILITY}

Preventing extremes of range of movement and reducing abnormal movement of the ankle is the most obvious role of ankle taping. $\mathrm{Re}-$ searchers measure non-weight-bearing (NWB) range of motion or mechanical instability in the frontal plane (the talar tilt) using $x$ rays. Tape reduced extremes of range of movement on normal subjects after 15 minutes' running over a figure of eight course. ${ }^{32}$ On patients with proven mechanical ankle instability, a zinc oxide Gibney basketweave technique significantly decreased the amount of NWB talar tilt. $^{33}{ }^{34}$ Those patients with the greatest instability received the greatest benefit from the tape. Taping also limited talar tilt in full weight bearing (FWB) in four judo players with chronic instability after 90 minutes' training. ${ }^{35}$ However, these results should be regarded with caution as, unlike other studies, they claim to have recorded zero degrees talar tilt with taping.

FWB investigations using kinetic and kinematic assessment showed that ankle tape did not alter loading patterns but did affect sagittal ankle range of motion, causing increased rotation about the metatarsal heads. ${ }^{36}$

Although taping does seems to improve mechanical instability, the restricting effect is lost after varying periods of exercise. Rarick et al claimed that $40 \%$ of the effect of taping was lost after 10 minutes of vigorous general circuit exercises. ${ }^{8}$ Frankney et al found similar reduction of about $50 \%$ after 15 minutes of standard vigorous exercises including jumping, pivoting, and running. ${ }^{9}$ Larsen recorded a $20 \%$ decrease after 20 minutes' start/stop running on uneven ground and jumping. ${ }^{34}$ Greene and Hilman found that a basketweave with heel lock and figure of eight technique resulted in $37 \%$ loosening in total passive range of motion $(P<0.01)$ after 20 minutes of volleyball training ${ }^{17}$; after three hours of training the loosening worsened to $63 \%$. Myburgh et al measured a $10-20 \%$ restriction loss in all movements except dorsiflexion after 60 minutes of squash. ${ }^{37}$ One study made a direct comparison between traditional taping methods and ankle braces, ${ }^{37}$ which used an electrogoniometer to measure and compare NWB restriction of ankle motion with zinc oxide tape or Elastoplast against a simple nonrigid elastic stocking-type support. The zinc oxide tape restricted plantarflexion/inversion movement after 10 minutes of squash. However, after one hour of squash there was no significant difference between the tape or support. Studies comparing the semirigid Donjoy ALP brace on normal subjects with tape showed contrasting results. ${ }^{17}{ }^{38}$ Gross et al performed NWB measurements of the foot after 10 minutes' running and showed that both methods provided equal and significant restrictions of inversion and eversion. ${ }^{38}$ Interestingly, they reported that most of the subjects found the brace more comfortable than the tape. 
Table 1 Comparison of orthoses and tape

\begin{tabular}{|c|c|c|c|}
\hline Author & Orthosis & Taping techniquet & Conclusionst \\
\hline Rovere et $a l^{9}$ & $\begin{array}{l}\text { Laced ankle } \\
\text { brace }\end{array}$ & $\begin{array}{l}\text { z.o. clb/w fig } 8 \\
\text { HL }\end{array}$ & $\begin{array}{l}\text { Risk of injury halved using } \\
\text { orthosis rather than tape }\end{array}$ \\
\hline Myburgh et $a l^{37}$ & Elastic stocking & z.o. b/w St HL & $\begin{array}{l}\text { z.o. tape better than orthosis and } \\
\text { Elastoplast to restrict NWB } \\
\text { ROM }\end{array}$ \\
\hline Gross et al ${ }^{15}$ & Aircast airstirrup & $\begin{array}{l}\text { Elastoplast } \\
\text { z.o. b/w fig } 8 \mathrm{HL}\end{array}$ & $\begin{array}{l}\text { Aircast airstirrup better than } \\
\text { tape to restrict NWB ROM }\end{array}$ \\
\hline Gross et $a l^{88}$ & Donjoy ALP & z.o. subtalar sling & No difference in NWB ROM \\
\hline Greene and Hilman ${ }^{17}$ & Donjoy ALP & z.o. b/w fig $8 \mathrm{HL}$ & $\begin{array}{l}\text { Donjoy ALP better than tape to } \\
\text { restrict NWB ROM }\end{array}$ \\
\hline Paris et $a l^{\beta 9}$ & $\begin{array}{l}\text { Swede-O- } \\
\text { universal }\end{array}$ & z.o. clgb/w & $\begin{array}{l}\text { Swede-O-universal better than } \\
\text { subtalar brace and tape to } \\
\text { restrict NWB ROM }\end{array}$ \\
\hline \multirow[t]{2}{*}{ Mackean $e t a P^{6}$} & $\begin{array}{l}\text { Subtalar brace } \\
\text { Aircast airstirrup }\end{array}$ & 2.o. clb/w & $\begin{array}{l}\text { Active ankle brace showed least } \\
\text { overall performance impairment }\end{array}$ \\
\hline & $\begin{array}{l}\text { Swede-O- } \\
\text { universal } \\
\text { Active ankle } \\
\text { brace }\end{array}$ & & \\
\hline \multirow[t]{2}{*}{ Frankney et al } & $\begin{array}{l}\text { Laced ankle } \\
\text { brace }\end{array}$ & Hinton-Boswell & $\begin{array}{l}\text { Hinton-Boswell better than } \\
\text { orthosis and other taping } \\
\text { techniques to restrict NWB } \\
\text { ROM }\end{array}$ \\
\hline & & $\begin{array}{l}\mathrm{b} / \mathrm{w} \\
\text { Gill }\end{array}$ & \\
\hline \multirow[t]{2}{*}{$\begin{array}{l}\text { Lindley and } \\
\text { Kernozek }^{55}\end{array}$} & Aircast airstirrup & z.o. clb/w St & $\begin{array}{l}\text { ALP showed decreased } \\
\text { functional NWB ROM }\end{array}$ \\
\hline & $\begin{array}{l}\text { Active ankle } \\
\text { brace } \\
\text { Donjoy ALP }\end{array}$ & & \\
\hline \multirow[t]{2}{*}{$\begin{array}{l}\text { Fitzgerald and } \\
\text { Callaghan }\end{array}$} & Vulcan & $\begin{array}{l}\text { z.o. gb/w fig } 8 \\
\text { HL }\end{array}$ & $\begin{array}{l}\text { No difference in kinetic gait } \\
\text { parameters between braces or } \\
\text { tape }\end{array}$ \\
\hline & $\begin{array}{l}\text { Swede-O- } \\
\text { universal } \\
\text { Aircast airstirrup } \\
\text { "Tubigrip" } \\
\text { Laced ankle } \\
\text { brace }\end{array}$ & & \\
\hline Verbrugge $^{63}$ & Aircast airstirrup & z.o. gb/w St HL & $\begin{array}{l}\text { No difference in motor } \\
\text { performance }\end{array}$ \\
\hline
\end{tabular}

$\star$ Unpublished data.

$\dagger$ z.o. = zinc oxide tape; $\mathrm{b} / \mathrm{w}=$ basketweave; $\mathrm{clb} / \mathrm{w}=$ closed basketweave; $\mathrm{gb} / \mathrm{w}=$ Gibney basketweave; fig $8=$ figure of eight; $\mathrm{HL}=$ heel locks; $\mathrm{St}=$ stirrups; NWB = non weight bearing; ROM = range of movement.

However, earlier work recorded no differences between the same brace and tape. ${ }^{17}$ The contradiction may be explained by the different taping techniques used in each study. In contrast, the semirigid "Swede-O-universal" and non-rigid "subtalar support" braces provided better NWB restriction on plantarflexion, dorsiflexion, inversion, and eversion than taping after 15 minutes of activity. ${ }^{39}$ Similar superiority over taping was recorded for the semirigid Aircast airstirrup on normal subjects for passive inversion/eversion ${ }^{15}$ and for an individually moulded orthosis (described as semirigid) on inversion after 20 minutes' exercise (table 1). ${ }^{40}$ Similarly, in injured athletes, a "strong" thermoplastic semirigid ankle brace significantly reduced talar and subtalar motions of plantarflexion, inversion, and adduction of 14 subjects with symptoms of chronic ankle instability. ${ }^{41}$ Kinetic and kinematic analysis has been performed to examine the Aircast airstirrup, which was found to reduce the mediolateral force component and maximum calcaneal eversion angles. This moderation of gait was considered to be within normal values for walking. ${ }^{42}$

It is this inability to maintain mechanical stability during exercise that raises fundamental questions about the efficacy of taping and bracing. It seems that tape and braces, however well applied, cannot withstand the huge forces involved in an inversion ankle sprain.

\section{FUNCTIONAL INSTABILITY}

More recently, researchers have become more interested in the concept of functional instability of the ankle and the role of taping and bracing to alleviate it. Freeman et al described functional instability as "a term...to designate the disability to which the patients refer when they say that their foot tends to 'give way'" (page 678). ${ }^{43}$ Taping and bracing may help through their effect on the neuromuscular mechanisms via cutaneous input, which improves the muscular responses. The most commonly investigated muscle group is the peroneii owing to their role in preventing ankle inversion, a position which causes most lateral ligament ankle sprains.

Two studies have been performed on normal, healthy subjects that indicate the importance of peroneii function and its role in preventing lateral ankle sprain. ${ }^{44}{ }^{45}$ Konradsen and Hojsgaard used electromyographic assessment of peroneus longus and brevis in nine patients running on a treadmill. ${ }^{44}$ They concluded that the foot-ankle complex requires an inversion (supinated) position at the pre-heel strike phase of the running cycle to stimulate the peroneii to correct for inversion strain. A further study simulated an ankle sprain by local anaesthetic regional block. ${ }^{45}$ It established that whereas passive joint angle reproduction was "virtually impossible" after the anaesthesia, active angle reproduction and peroneal reaction time were far less affected. It was concluded that a mechanically unstable ankle can be helped by the peroneii and other muscle activity. Later work by Feuerbach et al made similar observations about active angle reproduction of the ankle joint after anaesthetising two components of the lateral ligament complex. ${ }^{46}$

Experimental work on patients with mechanically unstable ankles and on control subjects has shown differences in peroneal function between the groups. Trends, but no statistically significant differences, have been found between the peroneal response times of patients with ankle instability and control groups. ${ }^{47}$ Comparisons between injured and good sides of patients with chronic instability showed reaction times of $68 \mathrm{~ms} v 84 \mathrm{~ms}^{27}$ and $49 \mathrm{~ms} v 65 \mathrm{~ms},{ }^{49}$ with the injured side having a longer reaction time. The differences between the figures in the two studies were probably due to dissimilar recording methods. Recent investigations discovered that peroneal reaction time rather than peroneal strength was a discriminating factor after ankle sprain. ${ }^{50}$

\section{Taping and bracing for ankle proprioception}

As has already been mentioned, although some limitation of ankle range of movement can be achieved with taping and bracing, it is doubtful whether tapes and braces will withstand the forces of an inversion sprain. As a result, some authors have investigated the protective role of taping and bracing in the chronically injured 
ankle against injury through proprioception and awareness of foot position. ${ }^{27}{ }^{51-54}$ Glick et al, using electromyographic analysis of runners, found that ankle taping allowed the peroneii muscle group to contract for a longer period of time at the pre-heel strike stage in four mechanically unstable ankles. ${ }^{50}$

Karlsson and Andreasson used a trapdoor mechanism on 20 subjects with chronic ankle instability and found that the Gibney basketweave technique significantly shortened the reaction time of the peroneii muscle group, thus bringing it closer to times on the normal side. ${ }^{27}$ They also noted that the more unstable the ankle, the greater the improvement. As well as the peroneii muscle group, deficits can also be shown in tests for proprioception, such as passive joint angle reproduction. This gives further insight into the complexity of functional instability of the ankle and the effect of tape. Jerosch et al compared two types of brace and a closed Gibney basketweave taping technique with figure of eight supplementation on 16 unstable ankles. ${ }^{51}$ Although they found significant differences in angle reproduction before the test between stable and unstable ankles (thus concurring with Lentell et $a t^{2}$ ), taping did not significantly improve this; the authors were unable to offer an explanation for this finding. Proprioception has also been evaluated by postural sway and single leg balancing tests. Robbins et al evaluated taping on estimation of perceived direction and amplitude on surface slope in FWB. ${ }^{53}$ In contrast with Jerosch et $a l^{51}$ they concluded that ankle taping did improve foot position awareness and so may have a role in the prevention of ankle sprain in athletes.

The Aircast airstirrup has also been shown to facilitate joint proprioception in uninjured ankles with an anaesthetised lateral ligament complex. This improvement in joint position sense was thought to be due to the stimulation by the brace of the cutaneous receptors in the foot and shank, which might have increased the afferent feedback. ${ }^{46}$

Table 2 Effect of orthoses on performance on tests of vertical jump, sprint and agility

\begin{tabular}{|c|c|c|c|c|}
\hline \multirow[b]{2}{*}{ Author } & \multirow[b]{2}{*}{ Orthosis } & \multicolumn{3}{|c|}{ Effect of orthoses on: } \\
\hline & & Vertical jump & Sprint & Agility \\
\hline Paris $^{57}$ & $\begin{array}{l}\text { Swede-O-universal } \\
\text { McDavid } \\
\text { New Cross }\end{array}$ & $\begin{array}{l}\text { No effect } \\
\text { No effect } \\
\text { Detrimental }\end{array}$ & $\begin{array}{l}\text { No effect } \\
\text { No effect } \\
\text { No effect }\end{array}$ & $\begin{array}{l}\text { No effect } \\
\text { No effect } \\
\text { No effect }\end{array}$ \\
\hline Burks et $a l^{99}$ & $\begin{array}{l}\text { Swede-O-universal } \\
\text { Kallassy }\end{array}$ & $\begin{array}{l}\text { Detrimental } \\
\text { Detrimental }\end{array}$ & & $\begin{array}{l}\text { No effect } \\
\text { No effect }\end{array}$ \\
\hline Bocchinfuso et a $f^{8}$ & $\begin{array}{l}\text { Aircast airstirrup } \\
\text { Active ankle brace }\end{array}$ & $\begin{array}{l}\text { No effect } \\
\text { No effect }\end{array}$ & $\begin{array}{l}\text { No effect } \\
\text { No effect }\end{array}$ & $\begin{array}{l}\text { No effect } \\
\text { No effect }\end{array}$ \\
\hline Robinson et al ${ }^{b 1}$ & "Plastic stiffeners" & & & Detrimental \\
\hline $\begin{array}{l}\text { Greene and Hilman }{ }^{17} \\
\text { MacPherson et al }\end{array}$ & $\begin{array}{l}\text { Donjoy ALP } \\
\text { Aircast airstirrup } \\
\text { Donjoy Rocketsoc }\end{array}$ & $\begin{array}{l}\text { No effect } \\
\text { No effect } \\
\text { No effect }\end{array}$ & $\begin{array}{l}\text { No effect } \\
\text { No effect }\end{array}$ & \\
\hline MacKean $e t a l^{6}$ & $\begin{array}{l}\text { Swede-O-universal } \\
\text { Active ankle brace } \\
\text { Aircast airstirrup }\end{array}$ & $\begin{array}{l}\text { Detrimental } \\
\text { No effect } \\
\text { No effect }\end{array}$ & $\begin{array}{l}\text { No effect } \\
\text { No effect } \\
\text { No effect }\end{array}$ & \\
\hline Greene and Wight ${ }^{16}$ & $\begin{array}{l}\text { Swede-O-universal } \\
\text { Donjoy ALP } \\
\text { Aircast airstirrup }\end{array}$ & & $\begin{array}{l}\text { No effect } \\
\text { No effect } \\
\text { Detrimental }\end{array}$ & \\
\hline Pienkowski et al ${ }^{62}$ & $\begin{array}{l}\text { Aircast airstirrup } \\
\text { Swede-O-universal } \\
\text { Kallassy }\end{array}$ & $\begin{array}{l}\text { No effect } \\
\text { No effect } \\
\text { No effect }\end{array}$ & $\begin{array}{l}\text { No effect } \\
\text { No effect } \\
\text { No effect }\end{array}$ & $\begin{array}{l}\text { No effect } \\
\text { No effect } \\
\text { No effect }\end{array}$ \\
\hline $\begin{array}{l}\text { Verbrugge }{ }^{63} \\
\text { Wiley and } \text { Nigg }^{64}\end{array}$ & $\begin{array}{l}\text { Aircast airstirrup } \\
\text { Malleoloc }\end{array}$ & $\begin{array}{l}\text { No effect } \\
\text { No effect }\end{array}$ & $\begin{array}{l}\text { No effect } \\
\text { No effect }\end{array}$ & $\begin{array}{l}\text { No effect } \\
\text { No effect }\end{array}$ \\
\hline
\end{tabular}

These studies assume that assessing ankle proprioceptive function with NWB or open kinetic chain position indicates that such methods of support will prevent trauma to the ankle and foot in the FWB or closed kinetic chain position. Some studies have addressed this problem by comparing braces with taping in the FWB position.

Hamill et al using kinetic and kinematic analysis compared a Gibney basketweave with an unspecified brace and found no significant differences between the two types of support, concluding that neither tape nor brace affected foot motion. ${ }^{54}$ Functional FWB outcome measures were recorded on healthy subjects comparing a lace up brace, the Aircast airstirrup, and a taping technique. ${ }^{51}$ Braces improved the proprioception and functional ability of the injured and normal ankles, whereas the taping technique had no effect. FWB video analysis has been used to compare the effect of a zinc oxide tape with various braces on dorsiflexion and plantarflexion of the ankle. ${ }^{55}$ Only the Donjoy ALP brace affected sagittal range of motion.

\section{Potentially negative effects of taping and bracing}

Although, to date, there has not been a specific study on the subject, there is little evidence to support the view that long term use of both forms of ankle support may result in detrimental effects to the tissues around the ankle or joints within the kinetic chain. Garrick and Requa found no increase in the frequency of knee sprains occurring as a result of using a high topped shoe and prophylactic taping. ${ }^{1}$ They further commented that the increased likelihood of an ankle support causing a knee injury was overshadowed by the protection that the ankle support offered. A similar claim was made by Glick et $a l^{50}$ but with few supporting data. Other studies have used kinetic and kinematic analysis to evaluate the potentially negative effects of taping of the ankle. Contradictory results have shown that ankle taping can have disadvantageous secondary effects around the metatarsal heads in walking, ${ }^{36}$ or that neither taping nor bracing causes any alteration in foot motion in running. ${ }^{54}$

In addition to adverse effects on the lower extremity, it has been the opinion of some researchers that the potential benefits of wearing ankle braces to prevent ankle injury must be weighed against the possible detrimental effect on actual performance of the athlete. ${ }^{56}$ The consensus is that the various braces available have little detrimental effect on sprint or agility tests, but the results for vertical jump tests are contradictory (table 2). These contradictory results may be due to between study differences of sample size, types of sports analysed, age and proficiency of the athlete selected.

MacKean et $a l^{56}$ considered functional performance between zinc oxide tape and three types of semirigid brace: Aircast airstirrup; Swede-O-universal; active ankle training brace. It was one of the few studies to assess metabolic 
cost of these types of support and found that the Aircast airstirrup increased both $\mathrm{Vo}_{2}$ and energy expenditure.

\section{Summary}

The studies reviewed suggest that both mechanical and functional stability of the ankle can be improved with taping. The restrictive effect is lost after short bouts of exercise, which indicates that the mechanical restriction of movement may be less important than the neuromuscular and sensory mechanisms; the peroneii muscle group, in particular, has been implicated. Ankle braces are being used increasingly by sportspeople as these devices are more convenient and cost effective than tape. Most studies have shown that braces restrict ankle movement less than taping without affecting performance. Furthermore, they retain their restrictive properties for longer periods after exercise, but have also been shown to have a proprioceptive role. Both taping and braces have been shown to prevent ankle sprains in basketball and soccer players, though the study design should be considered before applying tape or recommending a brace for the prevention of ankle sprains.

\section{Key points}

ANKLE TAPE AND BRACES

- Restrict range of movement

- Reduce reinjury rate

- Improve proprioception

- Limitation of movement is lost after exercise

- No negative effect on most performance tests

- Little negative effect on other joints.

BRACES

- Minimal expertise needed

- Reusable

- Readjustable

- Washable

- Non-allergic.

TAPE

- Individually applied

- Less bulky than brace

- Athletes' preference

- Caters for unusual anatomy.

1 Garrick JG, Requa RK. Role of external support in the prevention of ankle sprains. Med Sci Sports 1973;5:200-3.

2 Miller EA, Hergenroeder AC. Prophylactic ankle bracing Pediatr Clin North Am 1990;37:1175-85.

3 Tropp H, Askling C, Gillquist J. Prevention of ankle sprains. Am 7 Sports Med 1985;13:259-62.

4 Firer P. Effectiveness of taping for the prevention of ankle ligament sprains. Br $f$ Sports Med 1990;24:47-50.

5 Bennell K, McCrory P. The role of ankle support in the preBennell K, McCrory P. The role of ankle support in the
vention of ankle injury. Sport Health 1992;10:13-16.

6 Hollis JM, Blasier RD, Flahiff CM. Simulated lateral ankle Hollis JM, Blasier RD, Flahiff CM. Simulated lateral
ligamentous injury. Am $\mathcal{F}$ Sports Med 1995;23:672-7.

ligamentous injury. Am $\mathcal{F}$ Sports Med 1995;23:672-7.
7 Lowe MK. Basketball injuries to the ankle. Medicine and Exercise Nutrition and Health 1993;2:247-51.

8 Rarick GL, Bigley G, Karst P, Malina RM. The measurable support of the ankle joint by conventional methods of taping. F Bone foint Surg [Am] 1962;44:1183-90.

9 Frankney JR, Jewett DL, Hanks GA, Sebastianelli WJ. A comparison of ankle tape methods. Clin $\mathcal{F}$ Sport Med 1993; 3:20-5.

10 Pope ME, Renstrom P, Donnermeyer D, Morgenstern S. A comparison of ankle taping methods. Med Sci Sports Exerc 1987;19:143-7.

11 Muwunga CL, Quinton DN, Sloan JP, Gillies P, Dove AF. A new treatment of stable lateral ligament injuries of the ankle joint. Injury 1988;17:580-2.

12 Tweedy R, Carson T, Vicenzino B. Leuko and Nessa ankle braces:effectiveness before and after exercise. Aust $\mathcal{\Im} S c i$ Med Sport 1994;26:62-6.
13 Anderson DL, Sanderson DJ, Hennig EM. The role of external nonrigid ankle bracing in limiting ankle inversion. Clin $\mathcal{F}$ Sport Med 1995;5:18-24.

14 Kimura IF, Nawoczenski DA, Epler M, Owen MG. Effect of airstirrup in controlling ankle inversion stress. $\mathcal{F}$ Orthop Sports Phys Ther 1987;9:190-3.

15 Gross MTS, Bradshaw MK, Ventry LC, Weller KH. Comparison of support provided by ankle taping and semirigid orthosis. F Orthop Sports Phys Ther 1987;9:33-9.

16 Greene TA, Wight CR. A comparative support evaluation of three ankle orthoses before, during and after exercise. $\mathcal{F}$ Orthop Sports Phys Ther 1990;11:453-66.

17 Greene TA, Hilman SK. Comparison of support provided by a semirigid orthosis and adhesive ankle taping before, during and after exercise. Am $\mathcal{f}$ Sports Med 1990;18:498506.

18 Greene TA, Roland GC. A comparative isokinetic evaluation of a functional ankle orthosis on talocalcaneal function. F Orthop Sports Phys Ther 1989;11:245-52.

19 McCluskey GM, Blackburn TA, Lewis T. A treatment for ankle sprains. Am f Sports Med 1976;4:158-61.

20 Capasso G, Maffulli N, Vesta V. Ankle taping:supports given by different materials. Br $\mathcal{F}$ Sports Med 1989;23:239-40.

21 Viljakka T. Mechanics of knee and ankle bandages. Acto Orthop Scand 1986;57:54-8.

22 Stover CN. Air stirrup management of ankle injuries in the athlete. Am $\mathcal{F}$ Sports Med 1980;8:360-5.

23 Barrett J, Bilisko T. The role of shoes in the prevention of ankle sprains. Sports Med 1995;20:277-80.

24 Bahr R, Karlsen R, Ovrebo RV. Incidence and mechanism of acute ankle inversion injuries in volleyball. $A m \mathcal{F}$ Sports Med 1994;22:595-600.

25 Sitler M, Ryan J, Wheeler B, McBride J, Arciero R, Anderson $\mathrm{J}$, et al. The efficacy of semirigid ankle stabiliser to reduce acute ankle injuries in basketball. $\mathrm{Am} \mathcal{f}$ Sports $\mathrm{Med}$ 1994;22:454-61.

26 Surve I, Scwellnus MP, Noakes T, Lombard C. A fivefold reduction in the incidence of recurrent ankle sprains in soccer players using the sport stirrup orthosis. $A m \mathcal{F}$ Sports Med 1994;22:601-5.

27 Karlsson J, Andreasson GO. The effect of external ankle support in chronic lateral ankle joint instability. Am $\mathcal{F}$ Sports Med 1992;20:257-61.

28 Sitler MR, Horodyski M. Effectiveness of prophylactic ankle stabilisers for prevention of ankle injuries. Sports Med 1995:20:53-7.

29 Rovere GD, Clarke TJ, Yates SC, Burley K. Retrospective comparison of taping and ankle stabilisers in preventing ankle sprains. $A m \mathcal{F}$ Sports Med 1988;16:228-33.

30 Leanderson J, Wredmark T. Treatment of acute ankle sprain. Comparison of a semirigid brace and compression bandage in 73 patients. Acta Orthop Scand 1995;66:52931.

31 Anonymous. Residual disability after ankle joint injury (editorial). Lancet 1989;1:1056

32 Laughmann RK, Carr TA, Chao EY, Youdas JW, Sim FH Three dimensional kinematics of the taped ankle before and after exercise. Am $\mathcal{F}$ Sports Med 1980;8:425-31.

33 Vaes P, De Boeck H, Handelberg F, Opdecam P. Comparative radiological study of the influence of ankle joint strapping and taping on ankle instability. $\mathcal{F}$ Orthop Sports Phys Ther 1985;7:110-14

34 Larsen E. Taping the ankle for chronic instability. Acta Orthop Scand 1984;55:551-3.

35 Yamamoto T, Kigawa A, Xu T. Effectiveness of functional ankle taping for judo athletes: a comparison between judo bandaging and taping. Br $\mathcal{S}$ Sports Med 1993;27:1 10-12.

36 Carmines DV, Nunley JA, McElhanley J. Effects of ankle taping on the motion and loading patterns of the foot in taping on the motion and loading patterns

37 Myburgh KH, Vaughan CL, Issacs SK. The effects of ankle guards and taping on joint motion before, during and after a squash match. Am $\mathcal{f}$ Sports Med 1984;12:441-6.

38 Gross MT, Batten AM, Lamm AL, Lorren JL, Stevens JJ, Davis JM, et al. Comparison of Donjoy ankle ligament protector and subtalar sling taping in restricting foot and ankle motion before and after exercise. $\mathcal{F}$ Orthop Sports Phys The 1994;19:33-41.

39 Paris DL, Vardaxis V, Kokkaliaris J. Ankle ranges of motion during extended activity periods while taped and braced. fournal of Athletic Training 1995;30:223-8.

40 Hughes LY, Stetts DM. A comparison of ankle taping and a semirigid support. Phys Sports Med 1983;11:99-103.

41 Lofvenburg R, Karrholm J. The influence of an ankle orthosis on the talar and calcaneal motions in chronic lateral instability of the ankle. A stereophotogrammetric analysis. Am $₹$ Sports Med 1993;21:224-9.

42 Hamill J, Morin G, Clarkson PM, Andres RO. Exercise moderation of foot function during walking with a reusable semirigid ankle orthosis. Clinical Biomechanics 1988;3:153 8

43 Freeman MAR, Dean MRE, Hanman IWF. The etiology and prevention of functional instability of the foot. $\mathcal{f}$ Bon foint Surg [Br] 1965;47:678-85.

44 Konradsen L, Hojsgaard C. Pre heel strike peroneal muscle activity during walking with and without external support. Scand F Med Sci Sports 1993;3:99-103.

45 Konradsen L, Ravn JB, Sorensen AI. Proprioception at the ankle: the effect of anaesthetic blockade of ligament receptors. F Bone foint Surg [Br] 1993;75:433-6.

46 Feuerbach JW, Grabiner MD, Koh TJ, Weiker GG. Effect of an ankle orthosis and ankle ligament anesthesia on ankle joint proprioception. Am $\mathcal{F}$ Sports Med 1994;22:223-9. 
47 Nawoczenski DA, Owen MG, Ecker ML, Altman B, Epler $M$. Objective evaluation of peroneal response to sudden inversion stress. F Orthop Sports Phys Ther 1985;7:107-9.

48 Johnson MB, Johnson CL. Electromyographic response of peroneal muscles in surgical and non surgical injured ankles during sudden inversion. F Orthop Sports Phys Ther 1993;18:497-501.

49 Lofvenberg R, Karrholm J, Sundelin G, Ahlgren O Prolonged reaction time in patients with chronic lateral Prolonged reaction time in patients with chronic lateral
instability of the ankle. Am $\mathcal{F}$ Sports Med 1995;23:414-17.

instability of the ankle. Am f Sports Med 1995;23:414-17.
50 Glick JM, Gordon RM, Nishimoto D. The prevention and treatment of ankle injuries. Am F Sports Med 1976;4:13641.

51 Jerosch J, Hoffstetter I, Bork H, Bischof $M$. The influence of orthoses on the proprioception of the ankle joint. Knee Surg Sports Traumatol Arthrosc 1995;3:39-46.

52 Lentell G, Baas B, Lopex D, McGuire L, Sarrels M, Synder P. The contributions of proprioceptive deficits muscle function and anatomical laxity to functional instability of the ankle. F Orthop Sports Phys Ther 1995;21:206-15.

53 Robbins S, Waked E, Rappel R. Ankle taping improves proprioception before and after exercise in young men. $\mathrm{Br} \mathcal{F}$ Sports Med 1995;29:242-7.

54 Hamill J, Knutzen KM, Bates BT, Kirkpatrick G. Evaluation of two ankle appliances using ground reaction force tion of two ankle appliances using ground re
data. F Orthop Sports Phys Ther 1986;7:244-9.

55 Lindley TR, Kernozek TW. Taping and semirigid bracing may not affect ankle functional range of motion. fournal of may not affect ankle functional rang

56 MacKean LC, Bell G, Burnham RS. Prophylactic ankle bracing vs. taping: effects of functional performance in female basketball players. $\mathcal{F}$ Orthop Sports Phys Ther 1995;22:77-81.

57 Paris DL. The effects of Swede-O-, New Cross and $\mathrm{McDavid}$ ankle braces and adhesive ankle taping on speed, balance, agility and vertical jump. fournal of Athletic Training 1992;27:253-6.

58 Bocchinfuso C, Sitler M, Kimura IF. Effects of two semirigid ankle stabilisers on performance involving speed agility and vertical power. Fournal of Sports Rehabilitation 1994;3:125-34.

59 Burks RT, Bean BG, Marcus R, Barker HB. Analysis of athletic performance with prophylactic ankle devices. $A m \mathcal{F}$ Sports Med 1991;19:104-6.

60 MacPherson K, Sitler M, Kimura I, Horodyski M. Effects of a semirigid and softshell prophylactic ankle stabiliser on selected performance tests among high school footballers. $\mathcal{F}$ selected performance tests among high schoc
Orthop Sports Phys Ther 1995;21:147-52.

61 Robinson JR, Frederick EC, Cooper LB. Systematic ankle stabilisation and the effect on performance. Med Sci Sport Exerc 1986;18:625-8.

62 Pienkowski D, McMorrow M, Shapiro R, Caborn DNM Stayton J. The effect of ankle stabilisers on athletic performance: a randomised prospective trial. Am 7 Sports Med 1995;23:757-62.

63 Verbrugge JD. The effects of semirigid aircast airstirrup bracing vs. adhesive ankle taping on motor performance. $f$ bracing vs. adhesive ankle taping on mo
Orthop Sports Phys Ther 1996;23:320-5.

64 Wiley JP, Nigg BM. The effect of an ankle orthosis on ankle motion and performance. F Orthop Sports Phys Ther 1996;23:362-9. 